\title{
Koncepcja budowy zunifikowanej ostoi wagonu pasażerskiego
}

\begin{abstract}
W artykule przedstawiono założenia koncepcji unifikacji ostoi wagonu pasażerskiego opartej na idei konstrukcji bazowej. Omówiono uwarunkowania oraz możliwości konstrukcyjne realizacji takiego przedsięwzięcia. Zaprezentowano wyniki obliczeń wytrzymatości pudta $i$ wybranych elementów konstrukcyjnych dostosowanych do wymagań koncepcji.
\end{abstract}

\section{Wprowadzenie}

Potrzebę unifikacji konstrukcji nośnej ostoi wagonu pasażerskiego oraz podstawowe problemy związane $\mathrm{z}$ jej realizacją omówiono $\mathrm{w}$ pracy [1]. Przedstawiono tam wstępną koncepcję uniwersalnej ostoi opartą o budowę modułową. Podstawowym założeniem tego rozwiązania jest przyjęcie głównych elementów nośnych w postaci dwóch ostojnic, o długości i rozstawie takim samym jak w dotychczasowych konstrukcjach. Pomiędzy ostojnice byłyby wstawiane pozostałe elementy pogrupowane w moduły, wśród których można wyróżnić: moduł skrajny, środkowy oraz moduły do mocowania urządzeń podwoziowych.

Proponowana koncepcja budowy ostoi umożliwia dowolne skonfigurowanie ustroju nośnego, dostosowanego do potrzeb aktualnie realizowanej konstrukcji, pod warunkiem jednak znajomości występujących wszystkich urządzeń mocowanych do podwozia oraz ich rozplanowania już na początku procesu projektowania. Ponadto ostoja wykonana na takich zasadach wymaga odpowiednich zabiegów technologicznych (np. sposób spawania) a więc większej pracochłonności wykonania, aby uzyskać odpowiednią dokładność położenia powierzchni stanowiących podstawę do mocowania urządzeń podwoziowych.

\section{Koncepcja unifikacji ostoi wagonu oparta na konstrukcji bazowej}

Tworząc nową koncepcję budowy konstrukcji nośnej ostoi kierowano się faktem, że w jej części skrajnej układ elementów nośnych jest w dużej mierzy określony przez wymagania przepisów kolejowych (np. wysokość położenia urządzeń cięgłowozderznych oraz hamulcowych), a także uzależniony od typu wózka (np. sposób połączenia z ostoja). Unifikacja tej części ostoi jest więc łatwa do zaplanowania, gdyż możliwości ingerencji w rozmieszczenie tych urządzeń są ograniczone.

Wobec powyższego propozycje konstrukcyjnego rozwiązania części skrajnej przedstawione w koncepcji modułowej [1], pozostaną aktualne. Więc moduł skrajny mógłby składać się z belki skrętowej, grzbietowej, czołownicy i dwóch podłużnic równoległych do belki grzbietowej, położonych w przedłużeniu osi zderzaków. W takim ułożeniu elementów nośnych uwzględniono już sugerowaną i wstępnie sprawdzoną pod względem wytrzymałości [1] likwidację ukośnicy, którą ze względu na skomplikowane wykonanie węzła połączeń ostojnicy, belki skrętowej i wspomnianej ukośnicy zastapiono podłużnicami stanowiącymi przedłużenie istniejących. Konstrukcja takiego modułu uzależniona jest przede wszystkim od typu wózka, który wpływa na kształt ostoi w rejonie połączenia z pudłem. Można by więc stworzyć szereg modułów dla poszczególnych rodzajów wózków. Połączenie modułu z ostojnicami można zrealizować poprzez przyspawanie bezpośrednio do górnego pasa i środnika ostojnicy, natomiast $\mathrm{w}$ rejonie dolnego pasa do specjalnych wstawek zamocowanych na ostojnicy.

Zasadnicze różnice pomiędzy koncepcjami pojawiają się dopiero w części środkowej ostoi, a więc między belkami skrętowymi. Podstawowym założeniem jest takie zaprojektowanie tej cześci ostoi, żeby przekroje poprzeczne elementów nośnych wypełniających przestrzeń między ostojnicami były jak najniższe. Uzyskaną w ten sposób dodatkową przestrzeń poniżej niskiej poprzecznicy można wykorzystać do przeprowadzenia różnorodnych instalacji. Przekroje poprzeczne elementów nośnych muszą jednak gwarantować przeniesienie wszystkich podstawowych obciążeń eksploatacyjnych. Taka konstrukcja stanowilaby swoistą uniwersalną konstrukcję bazową dla różnych wagonów pasażerskich. Wówczas bowiem dolna płaszczyzna ostojnic w części środkowej wagonu jest w pełni dostępna dla mocowania urządzeń podwoziowych w dowolnie wybranym miejscu.

Podstawowymi elementami nośnymi ostoi pozostaną, tak jak w poprzedniej koncepcji, dwa ceowniki rozmieszczone na jej szerokości. Wszelkie elementy nośne położone pomiędzy belkami skrętowymi wykonane byłyby z kształtowników o wysokości dużo niższej niż dotychczasowe. Wstępnie założono, że 
wszystkie poprzecznice wykonane $\mathrm{z}$ ceownika giętego zastapionoby kształtownikami zamkniętymi prostokątnymi o wysokości o połowę mniejszej (rury prostokątne). Umożliwiłoby to uzyskanie dodatkowej przestrzeni o odpowiedniej wysokości ponad powierzchnią mocowania urządzeń podwoziowych i przestrzeń ta byłaby idealnym miejscem na umieszczenie tam wszystkich kanałów z różnorodnymi instalacjami, połączonych ze sobą w odpowiednie zestawy łatwe do montażu. Takie zestawy przygotowane poza wagonem mogą być przymocowane od dołu do obniżonych poprzecznic. Wykorzystanie tej przestrzeni do mocowania instalacji zasilających jest najbardziej optymalne ze względu na jej położenie w stosunku do urządzeń podwoziowych jak i wnętrza wagonu.

Do mocowania urządzeń podwoziowych $\mathrm{w}$ dowolnym miejscu wzdłuż ostoi pomiędzy belkami skrętowymi proponuje się zastosować połączenie za pomoca specjalnych belek poprzecznych, mocowanych do dolnych półek obu ostojnic. Po określeniu miejsca, w którym ma być poprzez wspomniane belki przytwierdzone urządzenie, w ceowniku ostojnic należy w rejonie łap mocujących wspawać odpowiednie wzmocnienia i wykonać otwory do mocowania.

Proponowany przekrój poprzeczny ostoi przedstawiono schematycznie na rys. 1 .

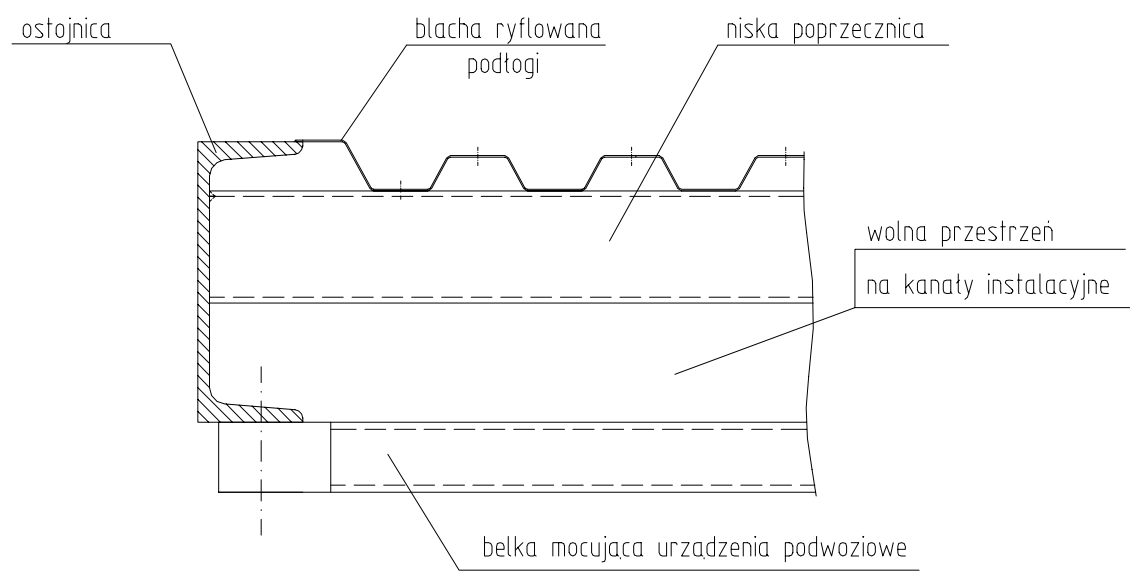

Rys.1. Schemat proponowanego przekroju poprzecznego

konstrukcji nośnej ostoi

\section{Analizy wytrzymałości związane z proponowaną koncepcją unifikacji ostoi wagonu}

Proponowana koncepcja unifikacji konstrukcji nośnej ostoi wagonu osobowego wymaga przeprowadzenia szeregu szczegółowych analiz. Oprócz wnikliwej analizy wymiarowej, potrzebnej w celu określenia położenia poszczególnych elementów względem siebie oraz skrajni taboru i budowli, konieczne jest sprawdzenie wytrzymałości proponowanych rozwiązań. W szczególności dotyczy to konstrukcji bazowej ostoi, która powinna zapewniać wystarczającą wytrzymałość na przeniesienie podstawowych obciążeń powstających podczas eksploatacji a określonych w przepisach karty UIC 566[2].

Dla potrzeb analizy wytrzymałości ostoi opracowano model obliczeniowy obejmujący całą konstrukcję pudła wagonu. W modelowaniu nadwozia i części skrajnej ostoi wykorzystano dokumentację konstrukcyjną ostatnio projektowanego wagonu pasażerskiego. Jest to wagon sypialny przeznaczony do ruchu międzynarodowego, którego pudło oparte jest na wózku typu 25ANa. Typ przyjętego wózka decyduje o kształcie ostoi w części skrajnej, a zwłaszcza belki skrętowej. W przyjętym modelu uwzględniono również sugerowaną wcześniej zmianę położenia ukośnicy w rejonie połączenia $\mathrm{z}$ belką skrętową. Część środkową ostoi zamodelowano zgodnie $\mathrm{z}$ założeniami koncepcji przedstawionymi w punkcie 2 . Przekroje poprzeczne elementów nośnych określono wstępnie na podstawie obliczeń uproszczonych modeli. Ogólny widok modelu obliczeniowego całego pudła wagonu zaprezentowano na rys.2 i 3 . Analizę wytrzymałości wykonano za pomoca metody elementów skończonych (MES) z zastosowaniem programu ABAQUS. Podstawowe obciążenia, a więc ściskanie w osiach zderzaków i w osi sprzęgu siłą $2,0 \mathrm{MN}$ oraz obciążenie pionowe a także kryteria oceny przyjęto zgodnie $\mathrm{z}$ wymaganiami karty UIC 566[2]. Otrzymane wyniki w postaci rozkładu naprężeń w konstrukcji pudła w żadnym punkcie nie przekraczają wartości dopuszczalnych.

W proponowanej koncepcji konstrukcji bazowej sposób ułożenia instalacji zasilających powoduje, że w części skrajnej wagonu powstaje konieczność przeprowadzenia ich poprzez elementy nośne ostoi. Aby nie pogorszyć ich nośności elementy te należy lokalnie wzmocnić. Dotyczy to głównie belki skrętowej. Na przykładzie belki skrętowej wykorzystanej w w/w modelu obliczeniowym, przeprowadzono porównawczą analizę wytrzymałości dotychczasowej konstrukcji (z jedną rurą przechodząca przez środniki) oraz konstrukcji umożliwiającej przeprowadzenie szeregu instalacji. Przeanalizowano dwa rozwiązania: 

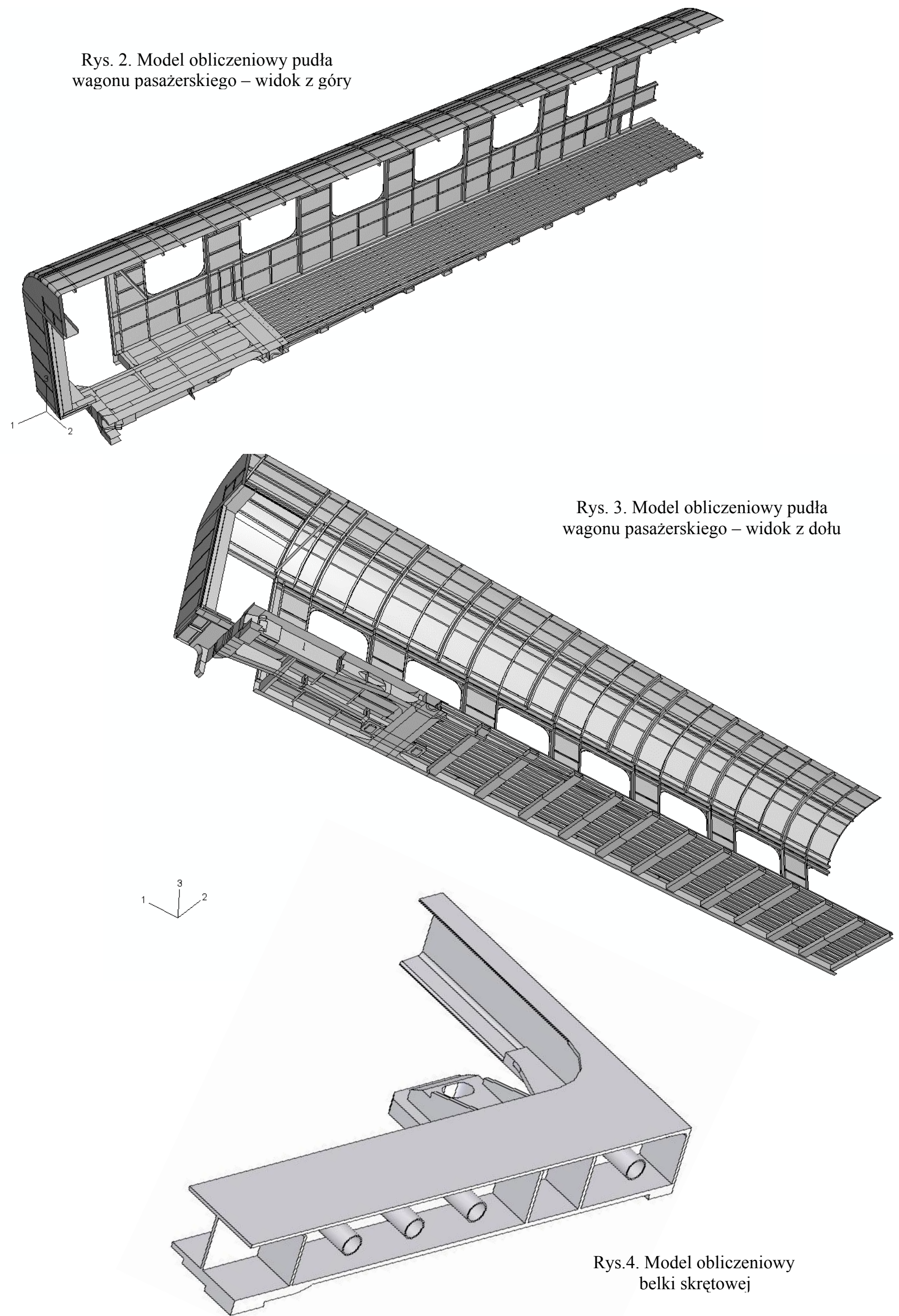
- zamiast jednej rury owalny otwór wzmocniony na jego obwodzie płaskownikiem i odpowiednio użebrowany

- zamiast jednej rury wprowadzono cztery rury o jednakowej średnicy odpowiednio daleko rozmieszczone od siebie.

Obciążeniem decydującym o wytrzymałości tego elementu jest obciążenie pionowe. $Z$ przeprowadzonych obliczeń wynika, że naprężenia wokół otworu w środniku w przypadku pierwszego rozwiązania wzrastaja prawie dwukrotnie w stosunku do dotychczasowej konstrukcji. Natomiast drugie rozwiązanie gwarantuje utrzymanie naprężeń na poziomie tylko niewiele wyższym niż dotychczas. Powyższe świadczy o tym, że bez najmniejszych przeszkód, korzystając $\mathrm{z}$ zaproponowanych rozwiązań, można przeprowadzić instalacje zasilające poprzez elementy nośne części skrajnej wagonu. Widok ogólny modelu obejmującego ćwiartkę analizowanej belki skrętowej przedstawiono na rys.4.

Wśród analiz przeprowadzonych w ramach opracowywania koncepcji unifikacji ostoi nie może zabraknąc sprawdzenia pod względem wytrzymałości belek mocujących urządzenia podwoziowe. Ze względu na konieczność mocowania urządzeń o zróżnicowanych masach wstępnie przyjęto podział urządzeń na dwie grupy: do 500kg i powyżej. Obciążenia obliczeniowe przyjęto zgodnie z kartą UIC 566 [2] określane dla sprawdzenia wytrzymałości mocowania wyposażenia. Są to siły wynikające $\mathrm{z}$ bezwładności przymocowanych mas.
Z przeprowadzonych obliczeń wytrzymałości wynika, że do mocowania mniejszych i lżejszych urządzeń podwoziowych (do $500 \mathrm{~kg}$ ) wystarczą dwie belki mocujące, rozstawione stosownie do gabarytu urządzenia. Dla pewności mocowania korzystne byłoby ich poprzeczne połączenie belkami. Przykład takiei konstrukcji mocuiacei przedstawiono na rys.5.

Dla większych i cięższych urządzeń (o masie do $1000 \mathrm{~kg}$ lub więcej), dla których producent przewiduje nawet kilkanaście punktów mocowania (np. agregaty klimatyzacyjne), w celu zapewnienia przeniesienia wszystkich obciążeń dynamicznych powstających podczas jazdy wagonu, konieczne będzie zastosowanie więcej niż dwóch belek mocujących, połączonych dodatkowo między sobą poprzecznicami, tworząc $\mathrm{w}$ ten sposób specyficzną ramę montażową. Ze względów bezpieczeństwa oraz zapewnienia wystarczającej wytrzymałości takich ram, zaprojektowanie uniwersalnych konstrukcji jest raczej mało prawdopodobne. Przeanalizowano pod względem obciążeń możliwości mocowania różnego typu urządzeń i z analizy wynika, że kształt ram montażowych w dużym stopniu uzależniony jest od wymiarów gabarytowych, masy, położenia środka ciężkości, sposobu mocowania i ilości punktów mocujących urządzenia. Wskazanym byłoby każdorazowo dla zamocowania większych i cięższych urządzeń podwoziowych, bazując na rozwiązaniu wzorcowym, zaproponować oraz sprawdzić wytrzymałość konkretnego rozwiązania.

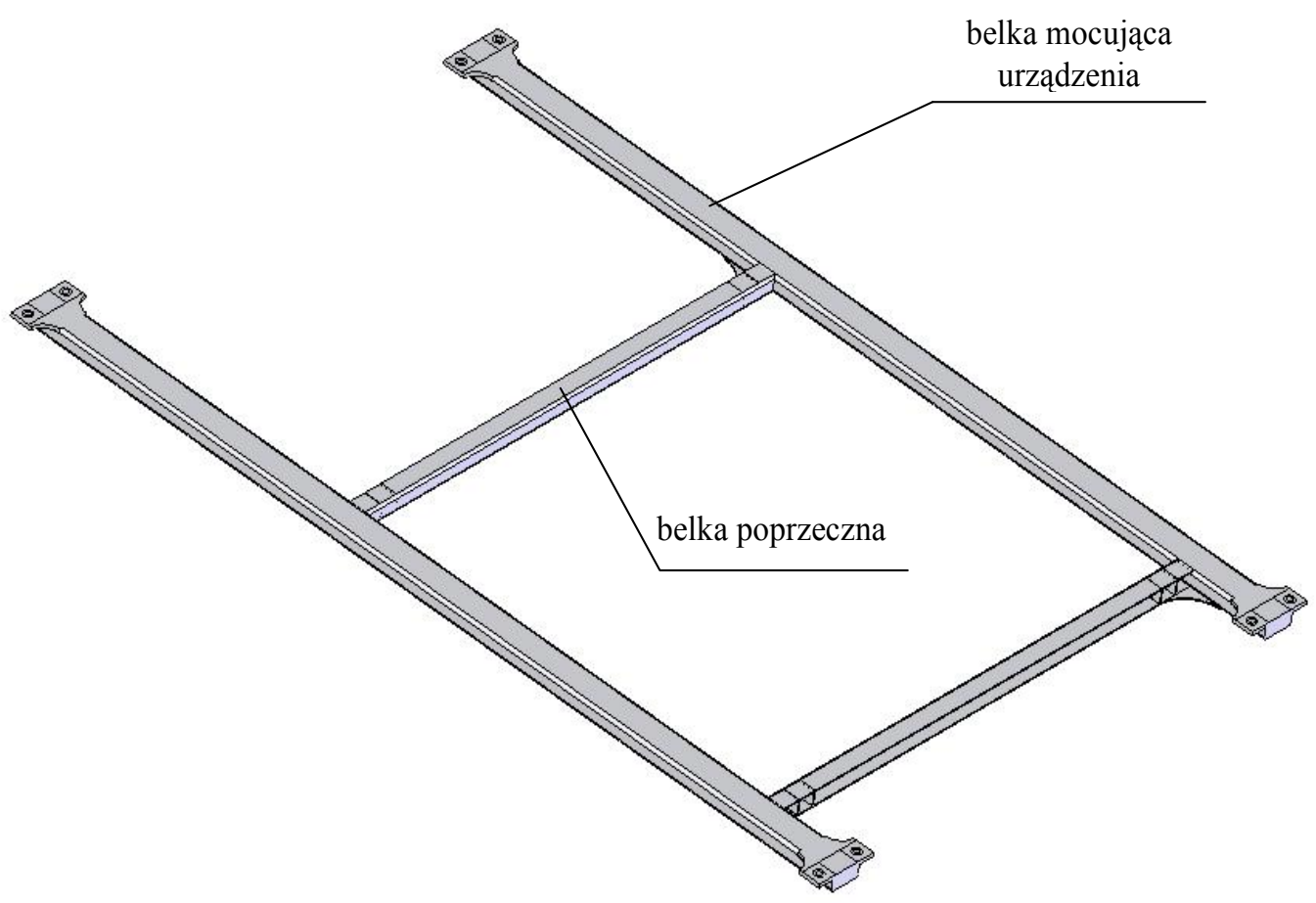

Rys.5. Wygląd ogólny konstrukcji mocującej lekkie urządzenia podwoziowe 


\section{Podsumowanie}

Reasumując można stwierdzić, że przedstawiona koncepcja unifikacji ostoi oparta na konstrukcji bazowej jest w stanie zapewnić uniwersalność budowy ustroju nośnego wagonu pasażerskiego, umożliwiając jednocześnie, stosownie do potrzeb, zabudowę urządzeń podwoziowych i wyposażenia.

\section{Literatura}

[1] Kuligowski P.: Wybrane zagadnienia zwiqzane $z$ unifikacja konstrukcji ostoi wagonu pasażerskiego typu Z, Pojazdy Szynowe, nr 3/2005

[2] Karta UIC 566: Obciażenia pudet wagonów pasażerskich i części dobudowanych. Wydanie 3 z 01.01.1990r. ze zmianami z 01.07.1994r. 